\title{
THE CONTRIBUTION OF RED WOOD ANTS TO SOIL C AND N POOLS AND $\mathrm{CO}_{2}$ EMISSIONS IN SUBALPINE FORESTS
}

\author{
Anita C. Risch,,${ }^{1,2,5}$ Martin F. Jurgensen, ${ }^{3}$ Martin Schütz, ${ }^{1}$ and Deborah S. Page-Dumroese ${ }^{4}$ \\ ${ }^{1}$ Swiss Federal Institute for Forest, Snow and Landscape Research, Zuercherstrasse 111, 8903 Birmensdorf, Switzerland \\ ${ }^{2}$ Mountain Forest Ecology, Department of Environmental Sciences, Swiss Federal Institute of Technology Zurich, \\ 8092 Zurich, Switzerland \\ ${ }^{3}$ Michigan Technological University, School of Forest Resources and Environmental Science, 1400 Townsend Drive, \\ Houghton, Michigan 49931 USA \\ ${ }^{4}$ USDA Forest Service, Rocky Mountain Research Station, Forestry Science Laboratory, 1221 S. Main Street, Moscow, \\ Idaho 83843 USA
}

\begin{abstract}
Little information is available regarding red wood ant (RWA; Formica rufa group) impacts on soil carbon (C) and nitrogen (N) cycling in forest ecosystems. We found that RWA mound density (number per ha) was linked to forest tree species composition, slope aspect, and canopy closure. The size of RWA mounds was positively correlated with successional age of the stands. $\mathrm{C}$ and $\mathrm{N}$ concentrations of mound material were significantly higher than in the forest floor, while $\mathrm{C}: \mathrm{N}$ ratios were not. RWA mound $\mathrm{C}$ and $\mathrm{N}$ pools were found to be significantly lower ( $\leq 990 \mathrm{~kg} \mathrm{C} / \mathrm{ha}$ and $\leq 21 \mathrm{~kg} \mathrm{~N} / \mathrm{ha}$ ) than in the forest floor. RWA mounds were "hot spots" for $\mathrm{CO}_{2}$ emissions ranging from 12.4 (mid July) to 3.5 (early September) times higher than the adjacent forest floor. Overall, they contributed 0.7$2.5 \%$ to total forest soil $\mathrm{CO}_{2}$ emissions. Consequently, the contribution of RWA to total forest soil $\mathrm{C}$ and $\mathrm{N}$ pools and forest $\mathrm{CO}_{2}$ emission is minor and likely not important when calculating or modeling $\mathrm{C}$ and $\mathrm{N}$ pools or $\mathrm{C}$ fluxes. Yet, RWAs increase the spatial heterogeneity of soil $\mathrm{C}$ and nutrients and alter the flow of energy within their habitat.
\end{abstract}

Key words: carbon dioxide; carbon and nutrient stores; closed chamber system; forest ßoor; high-elevation conifer forests; mineral soil; mound density; red wood ant; Swiss Alps.

\section{INTRODUCTION}

Ants are important components of most soil invertebrate communities. Besides their large contribution to biodiversity (Agosti et al. 2000), they are considered ecosystem engineers that alter the flow of energy and nutrients through terrestrial ecosystems (Jones et al. 1994) and provide habitats for other species (e.g., Hölldobler and Wilson 1990). While some research has been conducted on the role of ants on soil pedoturbation (overview in Lobry de Bruyn 1999), little is known on their influence on soil processes. While all soil-inhabiting ants have belowground nests, some species build an aboveground nest component composed of litter collected from the surrounding forest floor (e.g., Wisniewski 1976, Cherix 1986). These aboveground nests (mounds) can reach up to $2 \mathrm{~m}$ in height and $4 \mathrm{~m}$ in diameter (Gösswald 1989a). While only a few species of these organic-mound-building ants are found in North America (e.g., Formica exsectoides Forel, Formica obscuripes Forel; Wheeler 1960, Bishop and Bristow 2001), mound-building ants (Formica rufa group)

Manuscript received 19 January 2004; revised 21 May 2004; accepted 29 June 2004. Corresponding Editor: R. A. Dahlgren.

${ }^{5}$ Present address: Syracuse University, Department of Biology, 130 College Place, 207 Biological Research Laboratory, Syracuse, New York 13244 USA.

E-mail: arisch@syr.edu are ubiquitous in European conifer and mixed-conifer forests (e.g., Gösswald 1989a,b).

Because of their wide occurrence in European forests, these ants, collectively called red wood ants (RWA), have been the focus of extensive research on their social structure (Gösswald 1989a), geographical distribution and density (e.g., Kissling 1985), population dynamics and behavior (Klimetzek 1981), and their impact on biodiversity (Laakso and Setälä 1997, 2000, Hawes et al. 2002). RWAs have also been found to impact tree growth by feeding on leaf defoliators and protecting sap-sucking leaf aphids (Laakso and Setälä 2000).

Many studies have reported mound density (number of mounds per ha) or mound size from a wide range of European forests: Austria (Eichhorn 1963), Belgium (Ceusters 1979), Czech Republic (Frouz et al. 1997), Finland (Laakso and Setälä 2000), France (Torossian et al. 1979), Germany (Travan 1998), Great Britain (Sudd et al. 1977), Ireland (Breen 1979), Italy (Pavan 1962), Spain (Ceballos and Ronchetti 1965), and Sweden (Lenoir et al. 2001). However, many of these RWA studies did not have extensive mound inventories or give detailed information on stand age and tree species composition. Some individual RWA mound sizes and volumes were reported, but these measurements were not the main focus of most studies (Sudd et al. 1977, Ceusters 1979, Torossian et al. 1979, Coenen-Stass et al. 1980, Frouz et al. 1997). 
TABle 1. Description of the four forest types studied in the Swiss National Park (in order from early to late successional stage).

\begin{tabular}{|c|c|c|c|c|c|c|c|c|c|c|c|}
\hline \multirow[b]{3}{*}{ Stand type } & \multicolumn{11}{|c|}{ Forest stand properties } \\
\hline & \multirow{2}{*}{$\begin{array}{l}\text { No. } \\
\text { stands }\end{array}$} & \multicolumn{5}{|c|}{$\begin{array}{l}\text { Tree species composition } \\
\text { (\% of total basal area) }\end{array}$} & \multirow{2}{*}{$\begin{array}{c}\text { Canopy } \\
\text { closure } \\
(\%)\end{array}$} & \multirow{2}{*}{$\begin{array}{l}\text { Stand } \\
\text { height } \\
(\mathrm{m})\end{array}$} & \multirow{2}{*}{$\begin{array}{l}\text { Stand } \\
\text { age } \\
\text { (yr) }\end{array}$} & \multirow{2}{*}{$\begin{array}{c}\text { Basal } \\
\text { area } \\
\left(\mathrm{m}^{2} / \mathrm{ha}\right)\end{array}$} & \multirow{2}{*}{$\begin{array}{c}\text { Stand } \\
\text { density } \\
\text { (stems/ } \\
\text { ha) }\end{array}$} \\
\hline & & PIMO & PICE & LADE & PIAB & PISY & & & & & \\
\hline Mountain pine & 6 & 96 & 2 & 1 & & 1 & 43 & 14 & 165 & 25 & 1659 \\
\hline Larch/mountain pine & 2 & 35 & & 62 & 1 & 2 & 46 & 19 & 168 & 34 & 1275 \\
\hline Mixed & 5 & 17 & 1 & 32 & 34 & $1 \overline{6}$ & 54 & 25 & 200 & 42 & 784 \\
\hline Stone pine & 3 & 3 & 63 & 25 & 8 & 1 & 63 & 27 & 236 & 54 & 577 \\
\hline
\end{tabular}

Note: Key to abbreviations: PIMO = Pinus montana, $\mathrm{PICE}=$ Pinus cembra, $\mathrm{LADE}=$ Larix decidua, PIAB $=$ Picea abies, PISY $=$ Pinus sylvestris, $\mathrm{OM}=$ organic matter. Mineral soil properties are for surface soils, $0-20 \mathrm{~cm}$ depth.

$\dagger$ Determined by chamber and membrane plate method.

Although mound density of RWAs can be high (up to 18 mounds/ha) in certain forest types (Raignier 1948, Ceballos and Ronchetti 1965, Gris and Cherix 1977, Cherix and Bourne 1980), very little is known about the contribution of these mounds to forest soil carbon (C) and nitrogen (N) pools and soil processes. The chemical composition of RWA mound material differs considerably from the surrounding forest floor (Lenoir et al. 2001) and mineral soil (Frouz et al. 1997, Laakso and Setälä 1998, Lenoir et al. 1999). Higher numbers of soil microorganisms are present in RWA mounds than in the adjacent forest floor and mineral soil (Gösswald 1989a, Laakso and Setälä 1998). In addition, respiration from microorganisms and RWAs living in mounds, estimated to range from 200 to 10000 ants/ $\mathrm{dm}^{3}$ mound material (Kneitz 1965, Coenen-Stass et al. 1980 ) or $500000-1000000$ or more ants per mound (Rosengren et al. 1987, Gösswald 1989a), may be an important source of $\mathrm{CO}_{2}$ emissions. However, no information is available on total $\mathrm{C}$ and $\mathrm{N}$ contents or the amounts of $\mathrm{CO}_{2}$ given off by RWA mounds. Consequently, studies on belowground $\mathrm{C}$ and $\mathrm{N}$ pools (e.g., Perruchoud et al. 1999, Vucetich et al. 2000, Ritter et al. 2003) and $\mathrm{CO}_{2}$ emissions in European conifer forests (e.g., Widén 2002, Pumpanen et al. 2003, Subke et al. 2003) did not consider the contribution of RWA mounds in their calculations. Therefore, the objectives of our study were to (1) determine RWA mound density (numbers per ha) and mound volume in four different conifer forest types in the Central European Alps, (2) estimate the contribution of RWA mounds to soil C and $\mathrm{N}$ pools in these forests, and (3) compare $\mathrm{CO}_{2}$ emissions from RWA mounds to the surrounding soil surface.

\section{Site Description}

This study was conducted in the Swiss National Park (SNP), located in the southeastern part of Switzerland. The park covers an area of $170 \mathrm{~km}^{2}$ with elevations ranging from 1350 to $3170 \mathrm{~m}$ above sea level. Mean annual precipitation and temperature are $925 \pm 162$ $\mathrm{mm}$ and $0.2 \pm 0.7^{\circ} \mathrm{C}$ (mean $\pm 1 \mathrm{sE}$, measured at the park's weather station in Buffalora at $1980 \mathrm{~m}$ above sea level). Forests composed of mountain pine (Pinus montana Miller), Swiss stone pine (Pinus cembra L.), European larch (Larix decidua Miller), Scots pine (Pinus sylvestris L.), and Norway spruce (Picea abies (L.) Karst.) cover $50 \mathrm{~km}^{2}$ of the SNP. The early-successional forests are nearly pure stands of mountain pine; these are replaced by mixed-conifer stands. Most mixed forests contain all five conifer species, but stands dominated by larch/mountain pine are also found. The mixed forests are replaced by late-succession stone pine or stone pine/larch stands (Risch et al. 2003, 2004b).

As part of a continuing study on long-term forest dynamics, 16 forest stands were selected in proportion to their abundance in a 1957 forest inventory (Kurth et al. 1960). Six stands were dominated by mountain pine, two by larch/mountain pine, five contained all five tree species ("mixed"), and three were comprised of Swiss stone pine/larch ("stone pine"). A description of the stands studied is presented in Table 1. More detailed information on stand selection and soil sampling can be found in Risch et al. (2003, 2004a, b).

\section{Methods}

\section{RWA mound and forest ßoor sampling}

In each forest stand, RWA mounds were tallied in a $20 \mathrm{~m}$ radius circle around 16 systematically distributed sampling points (systematic grid of $70 \times 70 \mathrm{~m}$ or 40 $\times 40 \mathrm{~m}$, depending on stand size). Mound volume and surface area were calculated from height and two perpendicular diameters measured on each mound using the equation of half an ellipsoid (Sudd et al. 1977, Ceusters 1979, Gösswald 1989b). Samples for mound bulk density (BD) and chemical analyses were collected from six average-sized mounds per stand type (total of 24 mounds). One $150-\mathrm{cm}^{3}$ sample (core diameter $6.5 \mathrm{~cm}$ ) was taken at $0-10 \mathrm{~cm}$ and at $10-20 \mathrm{~cm}$ from the top of each mound. Since extensive RWA mound disturbance is restricted in the SNP, we were only able to collect one $150-\mathrm{cm}^{3}$ sample near the mound center (40-50 $\mathrm{cm}$ from top) from three mounds per stand type. Three circular forest floor samples (700 $\mathrm{cm}^{2}$ ) were collected at the center of each of the 16 
TABle 1. Extended.

\begin{tabular}{|c|c|c|c|c|c|c|c|c|c|}
\hline \multicolumn{10}{|c|}{ Slope and mineral soil properties } \\
\hline $\begin{array}{c}\text { Slope } \\
\text { exposure }\end{array}$ & $\begin{array}{l}\text { Slope } \\
\text { angle } \\
\left(^{\circ}\right)\end{array}$ & Texture & $\begin{array}{l}\text { Rock } \\
\text { content } \\
(\%)\end{array}$ & $\mathrm{pH}$ & $\begin{array}{c}\text { Available } \\
\text { water } \dagger \\
\text { (g/100 g soil) }\end{array}$ & $\begin{array}{l}\mathrm{OM} \\
(\%)\end{array}$ & $\begin{array}{l}\text { Bulk } \\
\text { density } \\
\left(\mathrm{g} / \mathrm{cm}^{3}\right)\end{array}$ & $\begin{array}{c}\mathrm{C} \\
\text { pools } \\
(\mathrm{Mg} / \mathrm{ha})\end{array}$ & $\begin{array}{c}\mathrm{N} \\
\text { pools } \\
(\mathrm{Mg} / \mathrm{ha})\end{array}$ \\
\hline S & 21 & Sandy loam & 32 & 6.2 & 12.2 & 14 & 1.3 & 91 & 3.3 \\
\hline ESE & 14 & Sandy loam & 33 & 6.6 & 6.8 & 12 & 1.2 & 57 & 2.9 \\
\hline SSE & 20 & Loamy sand & 30 & 5.5 & 11.5 & 7 & 1.4 & 54 & 2.7 \\
\hline NNW & 24 & Sand & 37 & 3.1 & 10.6 & 3 & 1.6 & 29 & 1.2 \\
\hline
\end{tabular}

stands. All RWA mound and forest floor samples were oven dried at $65^{\circ} \mathrm{C}$, ground to pass a $0.5 \mathrm{~mm}$ mesh screen, and analyzed for total $\mathrm{C}$ and $\mathrm{N}$ on a LECO induction furnace at $1000^{\circ} \mathrm{C}$ (LECO Corporation, St. Joseph, Michigan, USA). Subsamples were dried at $105^{\circ} \mathrm{C}$ to correct bulk density calculations. Organic matter (OM) content was determined by loss-of-ignition at $425^{\circ} \mathrm{C}$ (Ben-Dor and Banin 1989).

$$
\mathrm{CO}_{2} \text { emissions }
$$

We measured $\mathrm{CO}_{2}$ emissions with a PP-System EGM-4 infrared gas analyzer (PP-Systems, Hitchin, Hertfordshire, UK) on four mounds nearest to the stand center in each forest type (total of 16 mounds). Thirteen measurements were taken on two transects across each mound (Fig. 1) every second week from late June until mid-September (six sampling periods). Soil $\mathrm{CO}_{2}$ emission from the soil surface was also measured in each forest stand using the EGM-4 infrared gas analyzer on PVC collars inserted at five locations after snowmelt (Fig. 1).

\section{Statistical analyses}

Differences in number of RWA mounds, mound $\mathrm{BDs}$, mound and forest floor $\mathrm{C}$ and $\mathrm{N}$ concentrations, and pools among the different stand types were tested using a one-way ANOVA followed by a Tukey posthoc test for pairwise comparison (differences were considered significant at $P=0.05$ ). Because RWA mounds from the same stand may not be independent from each other, we used a nested ANOVA (stand within stand type) followed by Tukey pairwise comparison to test whether individual mound parameters (height, diameter, volume) differed among the four stand types. Number count data (number of RWA mounds/ha) were square-root transformed, while height, diameter, and volume were $\log$ transformed before analysis to increase normality and to reduce heterogeneity of variance. Differences between average RWA mound and forest floor $\mathrm{CO}_{2}$ emission of the four stand types were analyzed with a $t$ test for pairwise comparison using the data pairs for each measuring period. Overall differences in $\mathrm{CO}_{2}$ emissions of RWA mounds and forest floor among stand types were analyzed using repeatedmeasures ANOVA. A one-way ANOVA followed by contrast analysis was used to test differences among the four different measurement height groups (top, onethird, two-thirds, bottom). $\mathrm{CO}_{2}$ emission data were log transformed for all analyses to increase normality. Re-
Forest floor $\mathrm{CO}_{2}$ sampling

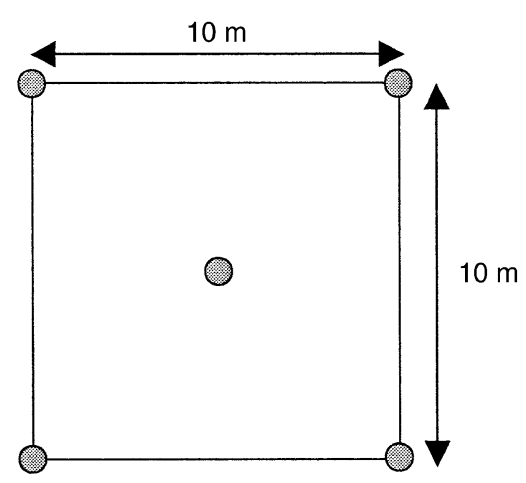

$10 \times 10 \mathrm{~m}$ plot at stand center

Forest floor $\mathrm{CO}_{2}$ measurement with PP-system chamber

\section{RWA mound $\mathrm{CO}_{2}$ sampling}

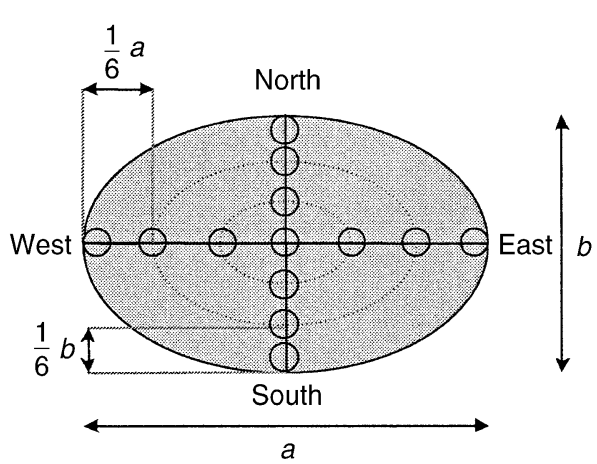

aerial view of an RWA mound with diameter $a$ and $b$

RWA mound $\mathrm{CO}_{2}$ measurement with PP-system chamber

FIG. 1. Design for sampling $\mathrm{CO}_{2}$ emissions from forest floor and red wood ant (RWA) mounds. 
TABLE 2. Characteristics of RWA mounds in high-elevation conifer forests in the Swiss National Park and in other European forests.

\begin{tabular}{|c|c|c|c|c|}
\hline Forest composition & Location & $\begin{array}{l}\text { Elevation } \\
\text { (m above } \\
\text { sea level) }\end{array}$ & $\begin{array}{l}\text { No. } \\
\text { mounds } \\
\text { per ha }\end{array}$ & $\begin{array}{l}\text { No. } \\
\text { mounds } \\
\text { in study }\end{array}$ \\
\hline \multicolumn{5}{|l|}{ This study } \\
\hline $\begin{array}{l}\text { P. montana } \dagger \\
\text { L. decidua, } P \text {. montana } \\
P \text {. abies, L. decidua, } P \text {. montana, } P \text {. sylvestris } \\
P \text {. cembra, L. decidua }\end{array}$ & $\begin{array}{l}\text { Switzerland } \\
\text { Switzerland } \\
\text { Switzerland } \\
\text { Switzerland }\end{array}$ & $\begin{array}{l}2006(28) \\
1850(30) \\
1792(25) \\
1963(32)\end{array}$ & $\begin{array}{r}6.4^{\mathrm{c}}(0.3) \\
10.9^{\mathrm{b}}(0.1) \\
13.3^{\mathrm{a}}(0.4) \\
6.0^{\mathrm{c}}(0.3)\end{array}$ & $\begin{array}{r}62 \\
51 \\
100 \\
29\end{array}$ \\
\hline \multicolumn{5}{|l|}{ Other studies, mixed-conifer forests } \\
\hline $\begin{array}{l}\text { L. decidua, P. abies, Abies alba } \\
\text { L. decidua, P. cembra, P. abies } \\
\text { P. sylvestris, Pinus nigra, Larix leptolepis, Pinus } \\
\quad \text { contorta, Picea sitkaensis (plantation) } \\
\text { P. abies, A. alba } \\
\text { P. abies, P. sylvestris }\end{array}$ & $\begin{array}{l}\text { Austria } \\
\text { United Kingdom } \\
\text { France } \\
\text { Finland }\end{array}$ & $\begin{array}{l}1100-1700 \\
1500-2150 \\
150\end{array}$ & $\begin{array}{l}5.6 \\
5.6 \\
1.6\end{array}$ & 324 \\
\hline $\begin{array}{l}\text { Single-species conifer forests } \\
\text { P. sylvestris } \\
\text { P. abies } \\
\text { P. abies (plantation) } \\
\text { P. abies (plantation) } \\
\text { P. abies } \\
\text { P. abies }\end{array}$ & $\begin{array}{l}\text { Sweden } \\
\text { Finland } \\
\text { Czech Republic } \\
\text { Belgium } \\
\text { Germany } \\
\text { Finland }\end{array}$ & $\begin{array}{l}380 \\
260-500 \\
\sim 70\end{array}$ & $\begin{array}{l}1-10 \\
2.0,13.8 \dagger \\
5 \\
1.2-6.1 \\
16.6\end{array}$ & $\begin{array}{l}1 \\
44-266 \\
9\end{array}$ \\
\hline $\begin{array}{l}\text { Mixed conifer-hardwood forests } \\
\text { Fagus sylvatica, P. abies, A. alba }\end{array}$ & Austria & $\begin{array}{l}950-1050 \\
1240 \ddagger\end{array}$ & $\begin{array}{r}3 \\
12 \\
6\end{array}$ & $\begin{array}{l}3 \\
5 \\
6\end{array}$ \\
\hline $\begin{array}{l}\text { P. sylvestris, Betula pubescens } \\
\text { Betula pendula, P. abies, P. sylvestris } \\
\text { B. pendula, P. abies, P. sylvestris } \\
\text { A. alba, F. sylvatica, L. decidua, P. abies, } \\
\text { P. sylvestris, Quercus spp. } \\
\text { Quercus spp., Pinus spp. } \\
\text { P. abies, Acer pseudoplatanus, F. sylvatica, } \\
\text { Salix grandifoli, Sorbus aucuparia } \\
\quad \text { (age } 70-90 \text { years) }\end{array}$ & $\begin{array}{l}\text { Finland } \\
\text { Sweden } \\
\text { Finland } \\
\text { Germany } \\
\text { Germany } \\
\text { Switzerland }\end{array}$ & $332-637$ & $\begin{aligned} & 3-6 \\
& 1-10 \\
& 9 \\
< & 0.1-0.2\end{aligned}$ & $\begin{array}{r}6 \\
10\end{array}$ \\
\hline $\begin{array}{l}\text { Hardwood forests } \\
\text { F. sylvatica, Quercus spp. } \\
\text { F. sylvatica }\end{array}$ & $\begin{array}{l}\text { Germany } \\
\text { Austria }\end{array}$ & $\begin{array}{l}332-637 \\
600-800\end{array}$ & $\begin{array}{c}<0.1 \\
0\end{array}$ & \\
\hline $\begin{array}{l}\text { Forest composition uncertain } \\
\text { A. alba, F. sylvatica, L. decidua, P. abies, } \\
\text { P. cembra, P. montana } \S\end{array}$ & France & $1500-2000$ & & $4-67$ \\
\hline $\begin{array}{l}\text { Conifer } \\
\text { Mixed conifer } \\
\text { Mixed conifer-hardwood } \\
\text { Unknown composition }\end{array}$ & $\begin{array}{l}\text { Poland } \\
\text { Germany }\end{array}$ & $700-1800$ & $\begin{array}{l}3.0-4.8 \\
4.4-4.5 \\
0.3-17.8\end{array}$ & 65 \\
\hline $\begin{array}{l}\text { Black forest (most likely monoculture } \\
\text { Norway spruce) }\end{array}$ & Germany & $300-700$ & $<0.1-0.2$ & 298 \\
\hline $\begin{array}{l}\text { Seven different stand types } \\
\text { Corylus spp., Betula spp., L. decidua, P. abies, } \\
\text { and } P \text {. cembra } \S\end{array}$ & $\begin{array}{l}\text { Austria } \\
\text { Germany }\end{array}$ & $\begin{array}{l}500->1500 \\
400-1800\end{array}$ & $<0.1$ & $\begin{array}{l}102-295 \\
408\end{array}$ \\
\hline
\end{tabular}

Notes: Dominant tree species are shown in boldface; otherwise species are listed alphabetically. Measurements of error are one standard deviation if shown with \pm , one standard error if shown in parentheses, and not available if nothing is shown. Values followed by the same lowercase letter are not significantly different $(P>0.05)$. Detailed stand descriptions for the present study are in Table 1.

$\dagger$ Results for old forest $(>100 \mathrm{yr})$, young forest $(14-25 \mathrm{yr})$.

+ Results for F. sylvatica $(40 \%), P$. abies $(30 \%)$, A. alba $(30 \%) ; F$. sylvatica, P. abies, almost no A. alba.

$\S$ Studies in different forest stands, but not well defined which stand had which species composition. 
TABle 2. Extended.

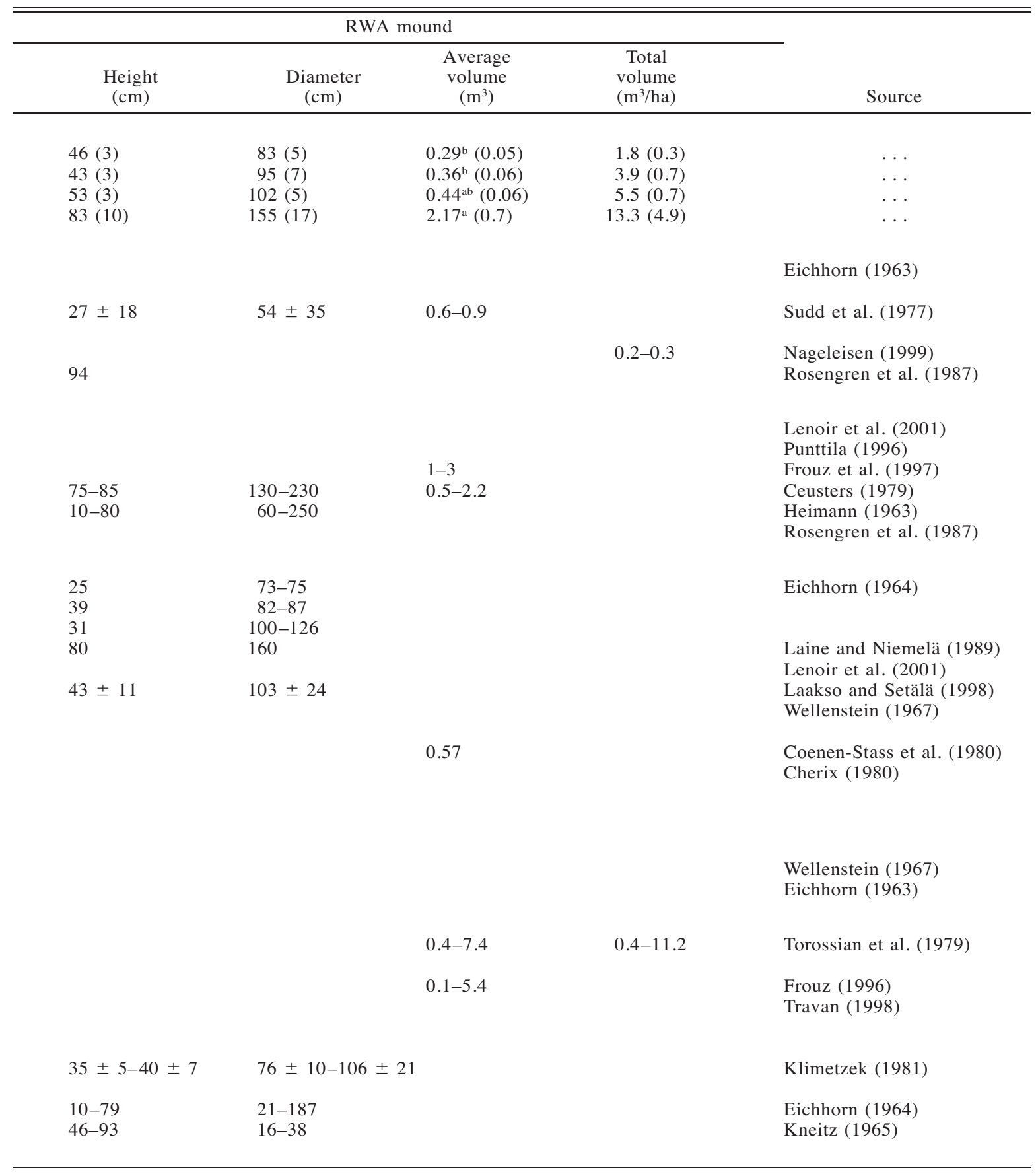


TABLE 3. Red wood ant mound and forest floor bulk density, organic matter, $\mathrm{C}$ and $\mathrm{N}$ concentration, $\mathrm{C}: \mathrm{N}$ ratios, and $\mathrm{C}$ and $\mathrm{N}$ pools in the Swiss National Park and in other European forests.

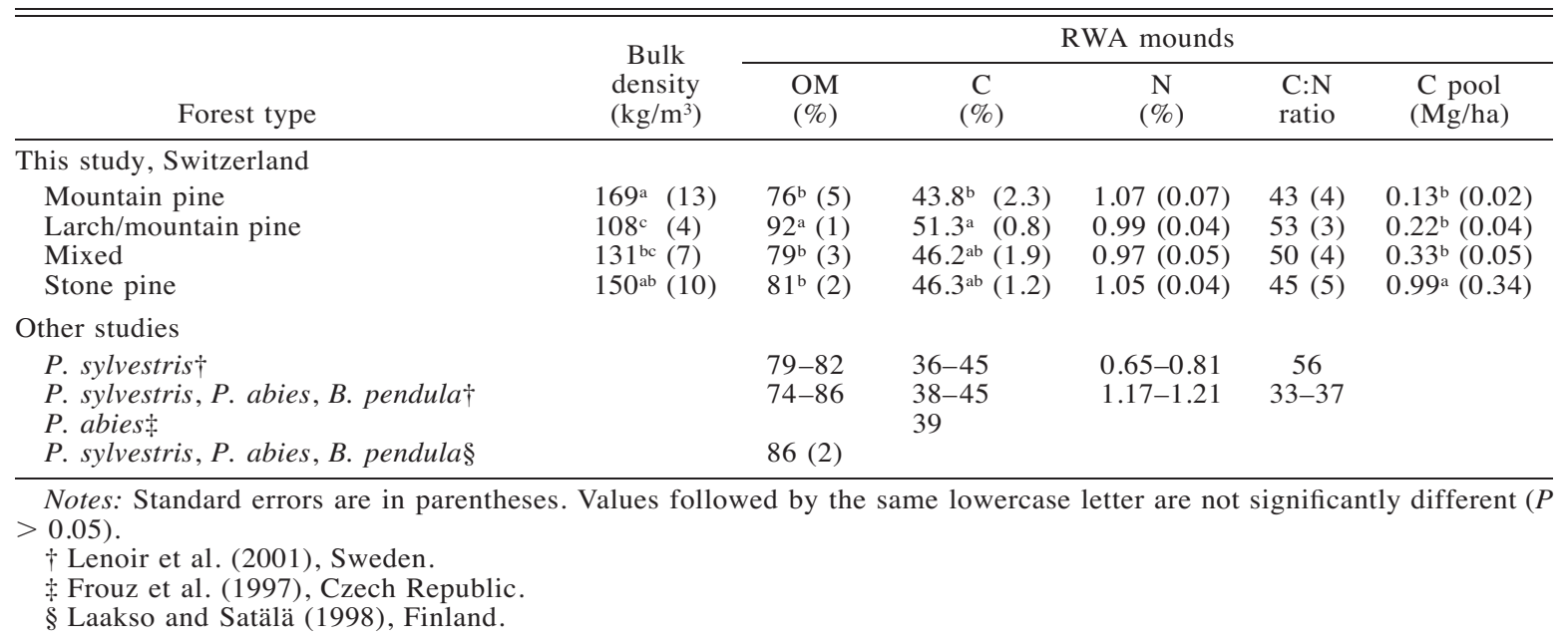

gression analysis was used to assess the correlation between RWA mound $\mathrm{CO}_{2}$ emission and mound size (volume and surface area).

\section{RESULTS}

RWA mound density, size, and volume

A total of 242 RWA mounds were recorded within the 16 forest stands studied. The number of mounds per hectare differed significantly among the forest types (Table 2). The highest numbers were found in mixedconifer forests, which also had the highest tree species diversity of the four stand types we sampled (Table 1). RWA mound height $(P=0.06)$ and diameter $(P=$ $0.07)$ were not significantly different among our four stand types, but individual mound volumes in the stone pine stands were significantly larger than in the mountain pine and mountain pine/larch stands. However, when calculated on a per-hectare basis, total RWA mound volumes did not significantly differ among the stand types $(P=0.14)$.

\section{$R W A$ mound $C$ and $N$ pools}

Bulk densities at different RWA mound depths (0$10 \mathrm{~cm}, 10-20 \mathrm{~cm}, 40-50 \mathrm{~cm}$ ) were not significantly different within each stand type. Therefore, we used an average mound $\mathrm{BD}$ to calculate mound $\mathrm{C}$ and $\mathrm{N}$ pools for each forest type (Table 3). Similar to BDs, $\mathrm{C}$ and $\mathrm{N}$ concentrations of our mound samples taken at different RWA mound depths did not differ significantly, and so we again used average stand type values to calculate mound $\mathrm{C}$ and $\mathrm{N}$ pools. RWA mounds in larch/mountain pine stands had significantly higher OM concentrations than mounds in the other stand types, but $\mathrm{N}$ concentrations and $\mathrm{C}: \mathrm{N}$ ratios were similar among stand types. Mound $\mathrm{C}$ only differed significantly between the mountain pine and the mountain pine/larch stands. C and $\mathrm{N}$ concentrations of RWA mounds were generally higher than the surrounding forest floor, but $\mathrm{C}: \mathrm{N}$ ratios were similar.

RWA mound $\mathrm{C}$ and $\mathrm{N}$ pools were significantly higher $(\mathrm{C}, P<0.001 ; \mathrm{N}, P<0.001)$ in stone pine stands, but did not differ among the other three stand types (Table $3)$. Expressed on an area basis, the amounts of $\mathrm{C}$ and $\mathrm{N}$ in RWA mounds were only a fraction of $\mathrm{C}$ and $\mathrm{N}$ stored in the forest floor, ranging from $0.6 \%$ to $5 \%$ (Table 3). If $\mathrm{C}$ and $\mathrm{N}$ present in the surface mineral soil $(0-20 \mathrm{~cm})$ is also included (Table 1$)$, the contribution of RWA mounds to total soil $\mathrm{C}$ and $\mathrm{N}$ pools is $<2 \%$. RWA nests also extend into the mineral soil, which has higher soil $\mathrm{C}$ and $\mathrm{N}$ contents than non-mound soil (Malozemova and Koruma 1973, Hulugalle 1995; Swiss National Park, unpublished data). However, the volume of mineral soil affected by RWA mounds is so small that it would not change the relationship of RWA mounds to total soil $\mathrm{C}$ and $\mathrm{N}$ pools.

\section{$\mathrm{CO}_{2}$ emissions}

Average $\mathrm{CO}_{2}$ emission for $16 \mathrm{RWA}$ mounds ranged between 0.8 and $8.6 \mathrm{~g} \mathrm{CO}_{2} \cdot \mathrm{m}^{-2} \cdot \mathrm{h}^{-1}$ over six sampling periods, but did not differ significantly among the four stand types $(P=0.24)$ due to large variability among mounds within each type. In general, $\mathrm{CO}_{2}$ emissions were correlated to mound volume $(r=0.50, P=0.046)$ and surface area $(r=0.58, P=0.01)$, were highest at the top of the mounds, and significantly decreased $(P$ $<0.005$ for all comparisons) with declining measurement height (top $>$ one-third $>$ two-thirds $>$ bottom). Emissions from RWA mounds and forest floor showed a seasonal trend $(P<0.001)$, both peaking in July and decreasing towards early September (Fig. 2).

Compared to the soil, RWA mounds were "hot spots" for $\mathrm{CO}_{2}$ emissions $(P<0.001)$, ranging from 12.4 (mid July) to 3.5 (early September) times higher than the adjacent forest floor (Figs. 2 and 3). However, 
TABle 3. Extended.

\begin{tabular}{|c|c|c|c|c|c|c|}
\hline \multirow{2}{*}{$\begin{array}{c}\text { RWA mounds } \\
\begin{array}{l}\text { N pool } \\
(\mathrm{kg} / \mathrm{ha})\end{array}\end{array}$} & \multicolumn{6}{|c|}{ Forest floor } \\
\hline & $\begin{array}{l}\mathrm{OM} \\
(\%)\end{array}$ & $\begin{array}{c}\mathrm{C} \\
(\%)\end{array}$ & $\begin{array}{l}\mathrm{N} \\
(\%)\end{array}$ & $\begin{array}{l}\mathrm{C}: \mathrm{N} \\
\text { ratio }\end{array}$ & $\begin{array}{c}\text { C pool } \\
(\mathrm{Mg} / \mathrm{ha})\end{array}$ & $\begin{array}{l}\mathrm{N} \text { pool } \\
(\mathrm{kg} / \mathrm{ha})\end{array}$ \\
\hline $\begin{array}{r}3.2^{\mathrm{b}}(0.6) \\
4.2^{\mathrm{b}}(0.8) \\
7.0^{\mathrm{b}}(1.0) \\
20.9^{\mathrm{a}}(7.7)\end{array}$ & $\begin{array}{l}74(3) \\
80(2) \\
66(5) \\
76(6)\end{array}$ & $\begin{array}{l}40.0(1.3) \\
42.5(1.9) \\
36.1(3.2) \\
35.5(5.4)\end{array}$ & $\begin{array}{l}0.89(0.04) \\
0.88(0.03) \\
0.82(0.04) \\
0.93(0.08)\end{array}$ & $\begin{array}{l}47(3) \\
48(1) \\
50(3) \\
39(3)\end{array}$ & $\begin{array}{l}23(5) \\
24(10) \\
16(6) \\
19(10)\end{array}$ & $\begin{array}{l}353(16) \\
376(31) \\
300(30) \\
408(56)\end{array}$ \\
\hline & $\begin{array}{l}81 \\
45\end{array}$ & $\begin{array}{l}44 \\
25 \\
35 \\
50(3)\end{array}$ & $\begin{array}{l}1.20 \\
0.96\end{array}$ & $\begin{array}{l}36 \\
28\end{array}$ & & \\
\hline
\end{tabular}

total RWA mound surface area in the four stand types were low ( 9 to $32 \mathrm{~m}^{2} / \mathrm{ha}$ ), and contributed only $0.7-$ $2.5 \%$ of the total soil $\mathrm{CO}_{2}$ emissions measured over the sampling period. Consequently, RWA mounds likely are not an important source of $\mathrm{CO}_{2}$ in the four forest types studied.

\section{Discussion}

\section{RWA mound density, size, and volume}

We found the highest RWA mound density in our south-southeast-exposed mixed-conifer forests. These results confirm findings from previous studies, which reported that (1) higher tree species diversity favors the development of RWA mounds by increasing the number and type of leaf aphids and other RWA food sources (Gösswald 1989a, b, Laine and Niemelä 1989), and (2) south-southeast-exposed slopes provide more suitable temperature and moisture conditions for RWA colonization (Forel 1920, Klimetzek 1970, Bretz 1971, Sossna 1973, Travan 1998). In contrast, a combination of minimal tree species diversity and high surface soil temperatures $\left(\sim 60^{\circ} \mathrm{C}\right.$; Swiss National Park, unpublished data) associated with relatively low canopy closure, probably was the cause for the low mound numbers in the mountain pine stand type (Adlung 1966, Kissling 1979, Travan 1998). Low temperature in the dense canopy, north-exposed stone pine stand type likely resulted in fewer but larger RWA mounds per hectare (Klimetzek 1970, Sossna 1973, Gösswald 1989a). The stone pine stands were also the oldest stands that we sampled, and likely contain older RWA mounds than younger, early-successional forests. RWA mounds usually increase in size as colonies become older (Wellenstein 1928, Gösswald 1989b), but little is known on the relationship of mound size to stand age in different forest types. Only a few studies have reported the age of forests in which the RWA mounds were located (Sudd et al. 1977, Cherix 1980, Punttila 1996).

RWA species distribution could also be a factor in the mound size differences we found. Dethier and Chérix (1982) showed that two RWA species (Formica lugubris ZETT. and Formica aquilonia YARROW) are present in the SNP forests. However, no correlation has been reported between mound size and RWA species (Sossna 1973, Gösswald 1989a), and is likely not related to RWAs mound size in the stand types.

Comparing our results from the SNP to other studies is difficult, since limited information is available on RWA in European subalpine forests (Table 2). Torossian et al. (1979) reported mound numbers for highelevation forests in France containing both stone pine and mountain pine, but information on tree species composition, slope aspect, and canopy closure in their stands were incomplete. A similar situation was found in the RWA study by Kneitz (1965) for high-elevation Austrian forests containing stone pine and larch. Eichhorn (1963) gave qualitative descriptions of the stone pine/larch stands he studied in Austria, but again, quantitative stand data were not reported. The same lack of stand and site information was found for many RWA studies conducted in other forest types at lower elevations (Table 2).

In general, most studies have shown that RWA prefer conifer forests or mixed conifer-hardwood stands over pure hardwood stands (Gösswald 1989b; Table 2). Low mound densities found in some low-elevation German and Austrian conifer or mixed conifer/hardwood stands during the 1960-1970 time period (Eichhorn 1963, Kneitz 1965, Wellenstein 1967, Klimetzek 1981) seem to contradict this general pattern. However, these stands were intensively managed and fragmented during the 19th and 20th century, were subjected to severe air pollution, and experienced extensive RWA mound destruction after the Second World War (Kneitz 1965, Gösswald 1989b, Travan 1998). We did not find newer studies from these forests to determine if RWA populations have increased since 1960-1970.

\section{$R W A$ mound $C$ and $N$ pools}

Even though RWA mounds have higher $\mathrm{C}$ and $\mathrm{N}$ concentrations than the surrounding forest floor and mineral soil, they do not contain significant amounts 


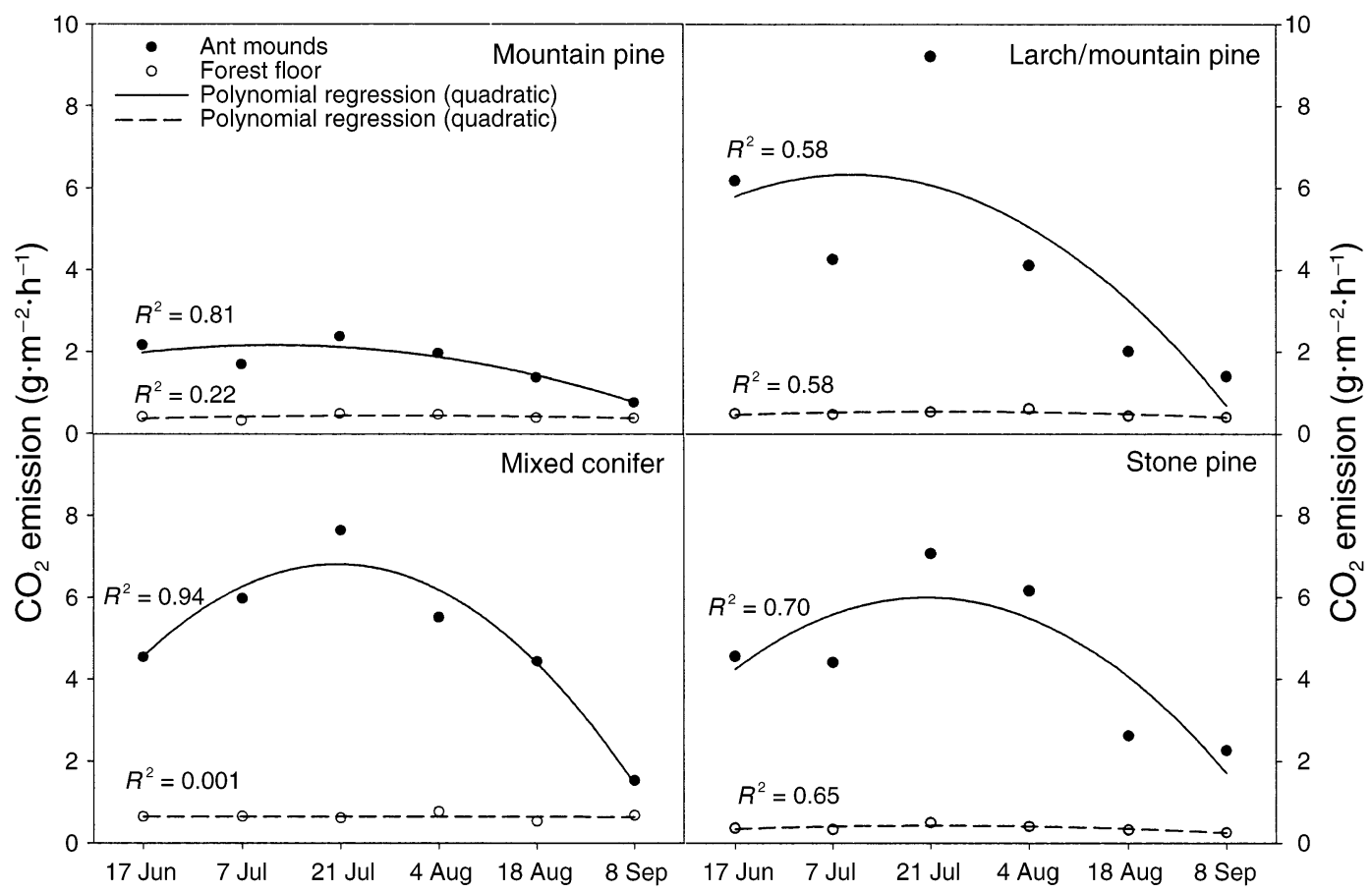

FIg. 2. Average $\mathrm{CO}_{2}$ emission rates from RWA mounds and forest floor in four forest stand types at six sampling dates between mid June and beginning of September 2003.

of total soil $\mathrm{C}$ and $\mathrm{N}$ in the forest ecosystems studied. However, RWAs periodically abandon their mounds when, e.g., the queen in a single-queen mound dies (e.g., Formica rufa L.), microclimatic conditions change during stand development, or food resources become scarce (Gösswald 1989a). This cycle of mound building and destruction would increase the spatial heterogeneity of soil $\mathrm{C}$ and nutrients throughout the ecosystem, which, in turn, eventually would increase plant biomass and productivity as suggested by Hutchings et al. (2003). Unfortunately, no information is available on mound abandonment rates, how fast abandoned mounds decompose, and how they impact soil $\mathrm{C}$ and $\mathrm{N}$ pools over long time periods.

Very little information is available on BD, OM, C, and $\mathrm{N}$ contents in RWA mounds. Our BD values are similar to RWA mounds in Finland (L. Finér and T. Domisch, personal communication) and Germany (Coenen-Stass et al. 1980). Gösswald (1989a) reported a higher RWA mound BD of $210 \mathrm{~kg} / \mathrm{m}^{3}$, but did not give any information on how this value was obtained or the numbers of mounds sampled. Lenoir et al. (2001) reported variable results for $\mathrm{OM}, \mathrm{C}$, and $\mathrm{N}$ concentrations in samples taken from RWA mounds and forest floor in Swedish Scots pine and Scots pine-Norway spruce stands (Table 3 ). In laboratory experiments, Lenoir et al. (2001) and Frouz (2000) found that decomposition rates of OM from RWA mounds were very slow when incubated under temperatures $\left(15^{\circ} \mathrm{C}\right)$ and moisture conditions ( $15 \%$ water-holding capacity) sim- ilar to the inside of mounds. Frouz et al. (1997) found higher $\mathrm{C}$ concentrations in a RWA mound than in the surrounding forest floor of a Norway spruce plantation in the Czech Republic. Similar results were reported by Laasko and Setäla (1998) for percent OM in mounds and forest floor from mixed conifer forests in Britain. However, in neither of these studies were OM, C, and $\mathrm{N}$ amounts in individual RWA mounds calculated or total RWA mounds pools estimated on an area basis.

\section{$\mathrm{CO}_{2}$ emissions}

The RWA mound emissions measured in our study can come from three sources: (1) respiration of RWAs and other invertebrates living in the mounds, (2) plant roots that grow into or beneath the mounds, and (3) microbial decomposition of mound OM (Gösswald 1989a, Lenoir et al. 2001, Pävinen et al. 2002). Even though mound temperatures have been reported to range between 15 and $28^{\circ} \mathrm{C}$ during most of the active season (Zahn 1957, Gösswald 1989a, Frouz 2000), decomposition rates of OM material are limited by low water content (Lenoir et al. 2001). Frouz (1996, 2000) reported gravimetric moisture contents of $4-70 \%$ in RWA mounds in Poland, while volumetric moisture contents of 2-5\% were found in Finnish RWA mounds (T. Domisch and M. Ohashi, personal communication). Root respiration by vascular plants is also likely to be very low, since RWA are quite effective in preventing plants growing on or close to the mounds (Gösswald $1989 a$ ). Therefore, the vast majority of $\mathrm{CO}_{2}$ emissions 

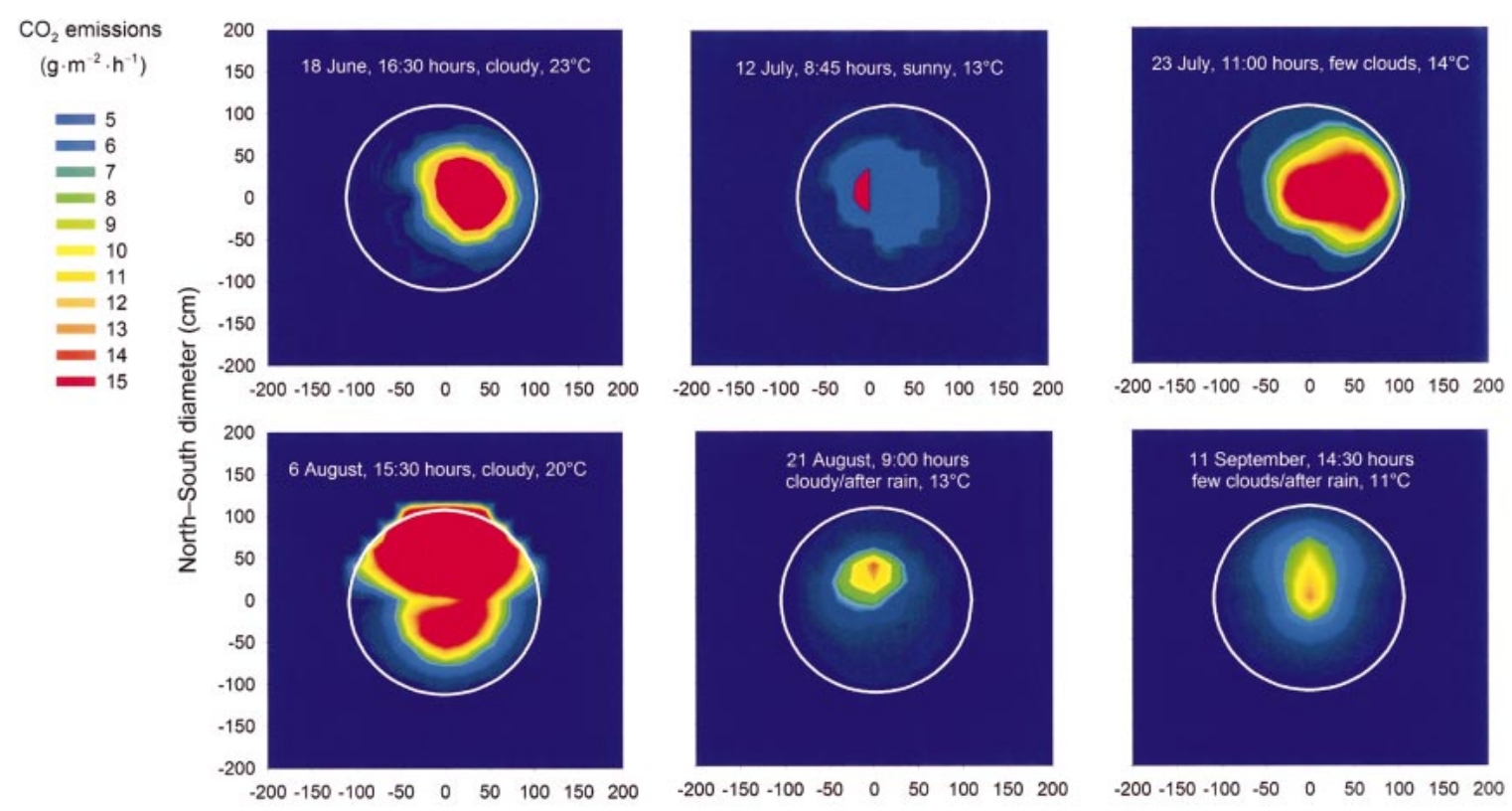

East-West diameter $(\mathrm{cm})$

FIG. 3. $\mathrm{CO}_{2}$ emission of one RWA mound between 17 June and 8 September 2003. The white ellipse indicates the aboveground basal extent of the mound (aerial view). Data points between the 13 sample locations were calculated by interpolation of the surrounding sample points.

measured in our study likely came from the respiration of RWA and other invertebrates living in the mounds.

While other groups of invertebrates live in RWA mounds (e.g., Hölldobler and Wilson 1990, Laakso and Setälä 1997), almost no information is available on their population size or on respiration rates. Studies conducted on RWAs workers (Formica rufa L.) reported an average respiration rate of $1.14 \times 10^{-5} \mathrm{~g}$ $\mathrm{CO}_{2} \cdot \mathrm{h}^{-1} \cdot$ worker $^{-1}(6.5 \mu \mathrm{L} / \mathrm{h})$ at $25^{\circ} \mathrm{C}$ (Holm-Jensen et al. 1980). Thus, 500000 to 1 million RWAs in large mounds (Rosengren et al. 1987, Gösswald 1989a) could produce 5.7-11.4 $\mathrm{g} \mathrm{CO}_{2} \cdot \mathrm{mound}^{-1} \cdot \mathrm{h}^{-1}$. While we do not know what percentage of the RWA colony was away from the mound when we measured $\mathrm{CO}_{2}$, our measurements of $2.8-15.3 \mathrm{~g} \mathrm{CO}_{2} \cdot \mathrm{m}^{-2} \cdot \mathrm{h}^{-1}$ for mounds larger than $1 \mathrm{~m}^{3}$, sampled on a warm summer day (beginning of August), are similar to these calculated rates.

RWA respiration would explain the higher $\mathrm{CO}_{2}$ emissions from the upper third of the mound surface where the breeding chamber ("heat core") is located (Gösswald 1989a). RWAs maintain temperatures of 25$30^{\circ} \mathrm{C}$ in this part of the nest by "bringing" heat from the mound surface into the center using their bodies as heat-carriers (Frouz 2000). This is especially important in spring, when large numbers of RWAs continually move from the warm surface to the colder interior of the mound (Rosengren et al. 1987, Gösswald 1989a). Thus, our spatial measurements would generally reflect the numbers and activity of RWAs in different parts of the mound during our sampling period, as is shown for one mound in Fig. 3. In contrast, the seasonal changes in RWA mound $\mathrm{CO}_{2}$ emission are likely associated with overall changes in RWA activity related to mound temperatures (Heimann 1963, Rosengren et al. 1987). Lower soil temperatures (air/soil) in the late summer/early fall are likely responsible for the seasonal trend found in forest floor emissions (e.g., Pumpanen et al. 2003).

\section{The importance of $\mathrm{RWAs}$ for $\mathrm{CO}_{2}$ emissions and $C$ and $N$ cycling}

Even though the contribution of RWA mounds to forest soil $\mathrm{C}$ and $\mathrm{N}$ pools was not found to be very large in the ecosystems we studied, RWAs increase the spatial heterogeneity of $\mathrm{C}$ and nutrients by assembling and consuming high amounts of prey and honey dew in their mounds (Rosengren and Sundström 1987, Gösswald 1989a, Hölldobler and Wilson 1990). They also increase habitat availability for other invertebrate species, which likely leads to higher forest biodiversity (McArthur and Wilson 1967). Thus, RWAs create "keystone structures," which are defined as spatial features that provide resources and habitat for other species (Tews et al. 2004).

Unlike termite nests, which were reported to contribute significant amounts of $\mathrm{CO}_{2}$ to the atmosphere (Zimmermann et al. 1982, Khalil et al. 1990, Konaté et al. 2003), RWA mounds added little to total soil $\mathrm{CO}_{2}$ emissions in the subalpine forests studied. Similar results were reported for mineral-mound-building fire ants (Solenopsis invicta [L.] Buren) in the southeastern 
United States (Bender and Wood 2003). Thus, ant mounds do not seem to be an important factor when calculating or modeling regional, national, or global $\mathrm{CO}_{2}$ budgets. However, more research on other ant species is needed, especially in the tropics, where ant biomass and diversity are much higher than in temperate and boreal ecosystems (Hölldobler and Wilson 1990, Agosti et al. 2000), and their contribution to soil $\mathrm{C}$ and nutrient pools and soil $\mathrm{CO}_{2}$ emissions may be larger.

\section{ACKNOWLEDGMENTS}

We would like to thank Daniel Cherix (University of Lausanne), Leena Finér, Timo Domisch, and Mizue Ohashi (University of Joensuu) for fruitful discussion in various stages of this project. We are grateful to Sabine Herzog and several volunteers for their help during data collection, and to Peter Holzer and Feihai Yu for their support with statistical analysis. We are indebted to Joanne Tirocke and Jenny Hensiek in Moscow, Idaho (USDA Forest Service) for their work in the laboratory on the mound samples. We thank Donat Agosti (University of California, Berkley) and the anonymous reviewers for constructive comments on the manuscript. This study was funded by the Swiss Federal Institute of Technology, Zurich (grant number TH-1'/01-1). We express our gratitude to the Swiss National Park Service for the administrative and logistic support of our research.

\section{Literature Cited}

Adlung, K. G. 1966. A critical evaluation of the European research on use of red wood ants (Formica rufa Group) for the protection of forests against harmful insects. Zeitschrift für angewandte Entomologie 57:167-189.

Agosti, D., J. D. Majer, L. E. Alonso, and T. R. Schultz. 2000. Ants: standard methods for measuring and monitoring biodiversity. Smithsonian Institution, Washington, D.C., USA.

Bender, M. R., and C. W. Wood. 2003. Influence of red imported fire ants on greenhouse gas emissions from a Piedmont plateau pasture. Communication in Soil Science and Plant Analysis 34:1873-1889.

Ben-Dor, E., and A. Banin. 1989. Determination of organic matter content in arid-zone soils using simple "loss-onignition" method. Communication in Soil Science and Plant Analysis 20:1675-1695.

Bishop, D. B., and C. M. Bristow. 2001. Effect of Allegheny mound ant (Hymenoptera: Formicidae) presence on Homopteran and predator populations in Michigan Jack Pine forests. Annals of the Entomological Society of America 94:33-40.

Breen, J. 1979. Nest sites of Formica lugubris Hymenoptera Formicidae in Irish plantation woods. Journal of Life Science, Royal Dublin Society 1:13-32.

Bretz, D. 1971. Wie bauen Waldameisen ihr Nest? Kosmos 67:200-204.

Ceballos, P., and F. G. Ronchetti. 1965. Le formiche del grouppo F. rufa sui Piranei orientali spagnoli nelle province di Nerida i Gero. Estretto delle Memorie Società Entomologica Italiana 45:153-168.

Ceusters, R. 1979. Données démographiques des diverses colonies polycaliques de Formica polyctena Foerst. Pages 31-60 in Compte rendue colloque annuel, Union international pour l'étude des insectes sociaux, Séction française, Septembre 7-8, Lausanne.

Cherix, D. 1980. Note prelimiaire sur la structure, la phénologie et le régime alimentaire d'une super-colonie de Formica lugubris Zett. Insects Sociaux 27:266-236.

Cherix, D. 1986. Les fourmis des bois ou fourmis rousses. Payot, Lausanne, Switzerland.

Cherix, D., and J. D. Bourne. 1980. A field-study on a supercolony of the RWA Formica lugubris Zett. in relation to other predatory arthropodes (spiders, harvestmen and ants). Revue suisse de Zoologie 87:955-973.

Coenen-Stass, D., B. Schaarschmidt, and I. Lamprecht. 1980. Temperature distribution and calorimetric determination of heat production in the nest of the wood ants, Formica polyctena (Hymenoptera, Formicidae). Ecology 61:238-244.

Dethier, M., and D. Cherix. 1982. Note sur les Formicidae du Parc National Suisse. Mitteilungen der Schweizerischen Entomologischen Gesellschaft 55:125-138.

Eichhorn, O. 1963. Die höhen und waldtypenmässige Verbreitung der nützlichen Waldameisen in den Ostalpen. Waldhygiene 5:129-135.

Eichhorn, O. 1964. Zur Verbreitung und Ökologie der hügelbauenden Waldameisen in den Ostalpen. Zeitschrift für angewandte Entomologie 54:253-289.

Forel, A. 1920. Les fourmis de la Suisse. Second edition. Société Helvetique des Sciences Naturelles, La Chaux-deFonds, Switzerland.

Frouz, J. 1996. The role of nest moisture in thermoregulation of ant (Formica polyctena, Hymenoptera, Formicidea) nests. Biologia Bratislava 51:541-547.

Frouz, J. 2000. The effect of nest moisture on daily temperature regime in the nests of Formica polyctena wood ants. Insectes Sociaux 47:229-235.

Frouz, J., H. Santruckova, and J. Kalcik. 1997. The effect of wood ants (Formica polyctena Foerst.) on the transformation of phosphorus in a spruce plantation. Pedobiologia 41:437-447.

Gösswald, K. 1989a. Die Waldameise. Band 1. Biologische Grundlagen, Ökologie und Verhalten. AULA, Wiesbaden, Germany.

Gösswald, K. 1989b. Die Waldameise. Band 2. Die Waldameise im Ökosystem Wald, ihr Nutzen und ihre Hege. AULA, Wiesbaden, Germany.

Gris, G., and D. Cherix. 1977. Les grandes colonies de fourmis des bois du Jura (groupe Formica rufa). Bulletin de la Societe Entomologique Suisse 50:249-250.

Hawes, C., A. J. A. Stewart, and H. F. Evans. 2002. The impact of wood ants (Formica rufa) on the distribution and abundance of ground beetles (Coleoptera. Carabidae) in a Scots pine plantation. Oecologia 131:612-619.

Heimann, M. 1963. Zum Wärmehaushalt der Kleinen Roten Waldameise (Formica polyctena Forest.). Waldhygiene 5: $1-21$.

Hölldobler, B., and E. O. Wilson. 1990. The ants. Harvard, Cambridge, Massachusetts, USA.

Holm-Jensen, I., T. F. Jensen, and M. G. Nielsen. 1980. The influence of temperature upon the rate of $\mathrm{CO}_{2}$ production in enflurane antesthetized worker of ants of Formica rufa L. Insectes Sociaux 27:180-185.

Hulugalle, N. R. 1995. Effects of ant hills on soil physical properties of a Vertisol. Pedobiologia 39:34-41.

Hutchings, M. J., E. A. John, and D. K. Wijesinghe. 2003. Toward understanding the consequences of soil heterogeneity of plant populations and communities. Ecology 84: 2322-2334.

Jones, C. G., J. H. Lawton, and M. Shachak. 1994. Organisms as ecosystem engineers. Oikos 69:373-386.

Khalil, M. A. K., R. A. Rasmussen, J. R. J. French, and J. A. Holt. 1990. The influence of termites on atmospheric trace gases: $\mathrm{CH}_{4}, \mathrm{CO}_{2}, \mathrm{CHCl}_{3}, \mathrm{~N}_{2} \mathrm{O}, \mathrm{CO}, \mathrm{H}_{2}$, and light hydrocarbons. Journal of Geophysical Research 95:36193634.

Kissling, E. M. 1979. Studie über die Biotop-Ansprüche von Waldameisen: Die Biotopansprüche von Formica lugubris in Poschiavo. Thesis. Eidgenössische Technische Hochschule Zurich, Zurich, Switzerland.

Kissling, E. M. 1985. Untersuchungen über die Biotopansprüche und einen allfälligen Rückgang von roten Walda- 
meisen aus der Formica rufa-Gruppe in der Schweiz. Dissertation. Eidgenössische Technische Hochschule Zurich, Zurich, Switzerland.

Klimetzek, D. 1970. Zur Bedeutung des Kleinstandortes für die Verbreitung hügelbauender Waldameisen der Formica rufa-Gruppe (Hymenoptera: Formicidae). Zeitschrift für angewandte Entomologie 66:45-48.

Klimetzek, D. 1981. Population studies on hill building wood-ants of the Formica rufa-Group. Oecologia 48:418421.

Kneitz, G. 1965. Formica-Arten mit vegetabilischem Nestbau in den Gurktaler Alpen (Kärnten). Waldhygiene 5:240250 .

Konaté, S., X. Le Roux, B. Verdier, and M. Lepage. 2003. Effect of underground fungus-growing termites on carbon dioxide emission at the point and landscape scales in an African savanna. Functional Ecology 17:305-314.

Kurth, A., A. Weidmann, and F. Thommen. 1960. Beitrag zur Kenntnis der Waldverhältnisse im Schweizerischen Nationalpark. Mitteilungen der Schweizerischen Anstalt für das forstliche Versuchswesen 36:221-379.

Laakso, J., and H. Setälä. 1997. Nest mounds of red wood ants (Formica aquilonia): hot spots for litter-dwelling earthworms. Oecologica 111:565-569.

Laakso, J., and H. Setälä. 1998. Composition and trophic structure of detrital food web in ant nest mounds of Formica aquilonia and in the surrounding forest soil. Oikos 81:266278.

Laakso, J., and H. Setälä. 2000. Impacts of wood ants (Formica aquilonia Yarr.) on the invertebrate food web of the boreal forest floor. Annales Zoologici Fennici 37:93-100.

Laine, K. J., and P. Niemelä. 1989. Nests and nest sites of RWAs (Hymenoptera, Formicidae) in subarctic Finland. Annales Entomologici Fennici 55:81-87.

Lenoir, L., J. Bengtsson, and T. Persson. 1999. Effects of coniferous resin on fungal biomass and mineralisation processes in wood ant nest materials. Biology and Fertility of Soils 30:251-257.

Lenoir, L., T. Persson, and J. Bengtsson. 2001. Wood ant nests as potential hot spots for carbon and nitrogen mineralization. Biology and Fertility of Soils 34:235-240.

Lobry de Bruyn, L. A. 1999. Ants as bioindicators of soil function in rural environments. Agriculture Ecosystems and Environment 74:425-441.

Malozemova, L. A., and N. P. Koruma. 1973. Effect of ants on soil. [English translation.] Ekologiya 5:98-101.

McArthur, R. H., and E. O. Wilson. 1967. The theory of island biogeography. Princeton University Press, Princeton, New Jersey, USA.

Nageleisen, L.-M. 1999. Etude de la densité et du rôle bioindicateur des fourmis rousses dans les foréts du nord-est. Revue Foréstiere Francaise 4:487-495.

Pavan, M. 1962. Premesi ed attuazioni per l'utilizazione delle Formiche del grouppo Formica rufa per la difesa delle foreste. Accademia Nazionale dei Lincei: Atti Convegno Equilibri biologici and insetticidi. Quaderno 58:33-42.

Pävinen, J., P. Ahlroth, and V. Kaitala. 2002. Ant-associated beetles of Fennoscandia and Denmark. Entomologica Fennica 13:20-40.

Perruchoud, D., F. Kienast, E. Kaufmann, and U. Bräker. 1999. 20th century carbon budget of forest soils in the Alps. Ecosystems 2:320-337.

Pumpanen, J., H. Ilvesniemi, M. Permäkäki, and P. Hari. 2003. Seasonal patterns of soil $\mathrm{CO}_{2}$ efflux and soil air $\mathrm{CO}_{2}$ concentration in a Scots pine forest: comparison of two chamber techniques. Global Change Biology 9:371-382.

Punttila, P. 1996. Succession, forest fragmentation, and the distribution of wood ants. Oikos 75:291-298.
Raignier, A. 1948. L'économie thermique d'une colonie polycalique de la Fourmi des bois. La Cellule 51:279-367.

Risch, A. C., M. F. Jurgensen, D. S. Page-Dumroese, and M. Schütz. 2004a. Above- and belowground carbon and nutrient pools during succession following land use change in subalpine ecosystems of the Central European Alps. Pages 56-85 in A. C. Risch, editor. Above- and belowground patterns and processes following land use change in subalpine conifer forests of the Central European Alps. Dissertation. Eidgenössische Technische Hochschule Zurich, Zurich, Switzerland.

Risch, A. C., L. M. Nagel, M. Schütz, B. O. Krüsi, F. Kienast, and H. Bugmann. 2003. Structure and long-term development of subalpine Pinus montana Miller and Pinus cembra L. forests in the central European Alps. Forstwissenschaftliches Centralblatt 122:219-230.

Risch, A. C., M. Schütz, B. O. Krüsi, F. Kienast, O. Wildi, and H. Bugmann. 2004b. Detecting successional changes in long-term empirical data from subalpine conifer forests. Plant Ecology 172:95-105.

Ritter, E., L. Vesterdal, and P. Gundersen. 2003. Changes in soil properties after afforestation of former intensively managed soils with oak and Norway spruce. Plant and Soil 249:319-330.

Rosengren, R., W. Fortelius, K. Lindström, and A. Luther. 1987. Phenology and causation of nest heating and thermoregulation in red wood ants of the Formica rufa group studied in coniferous forest habitats in southern Finland. Annales Zoologici Fennici 24:147-155.

Rosengren, R., and L. Sundström. 1987. The foraging system of a red wood ant colony (Formica s. str.). Pages 117-138 in J. M. Pasteels and J. J. L. Deneubourg, editors. From individual to collective behaviour in social insects. Experientia Supplement 54.

Sossna, H. 1973. Untersuchungen zur Abhängigkeit des Nestbauverhaltens der Waldameise Formica polyctena von den Umweltfaktoren Wärme, Licht und Feuchtigkeit im Labor. Zulassungsarbeit University, Würzburg, Germany.

Subke, J. A., M. Reichstein, and J. D. Tenhunen. 2003. Explaining temporal variation in soil $\mathrm{CO}_{2}$ efflux in a mature spruce forest in Southern Germany. Soil Biology and Biochemistry 35:1467-1483.

Sudd, J. H., J. M. Douglas, T. Gaynard, D. M. Murray, and J. M. Stockdale. 1977. The distribution of wood-ants (Formica lugubris Zetterstedt) in a northern English forest. Ecological Entomology 2:301-313.

Tews, J., U. Brose, V. Grimm, K. Tielbörger, M. C. Wichmann, M. Schwager, and F. Jeltsch. 2004. Animal species diversity driven by habitat heterogeneity/diversity: the importance of keystone structures. Journal of Biogeography 31:79-92.

Torossian, C., L. Ruques, and J. S. Gion. 1979. Les fourmis du groupe Formica rufa des Hautes-Alps. Pages 87-99 in Compte rendue colloque annuel, Union international pou l'étude des insectes sociaux, Séction française, Septembre 7-8, Lausanne.

Travan, J. 1998. Über den Einfluss von Standortsfaktoren auf die Besiedlung des bayerischen Hochgebirges durch Waldameisen (Formica spp.) (Hymen., Formicidae). Anzeiger für Schädlingskunde, Pflanzenschutz und Umweltschutz 71:105-109.

Vucetich, J. A., D. D. Reed, A. Breymeyer, M. Degorski, G. D. Mroz, J. Solon, E. Roo-Zielinska, and R. Noble. 2000. Carbon pools and ecosystems properties along a latitudinal gradient in northern Scots pine (Pinus sylvestris) forests. Forest Ecology and Management 136:135-145.

Wellenstein, G. 1928. Beiträge zur Biologie der roten Waldameise (Formica rufa L.) mit besonderer Berücksichtigung klimatischer und forstlicher Verhältnisse. Zeitschrift für angewandte Entomologie 14:1-68. 
Wellenstein, G. 1967. Zur Frage der Standortansprüche hügelbauender Waldameisen (Formica rufa-Gruppe). Zeitschrift für angewandte Zoologie 54:139-166.

Wheeler, W. M. 1960. Ants. Columbia University, New York, New York, USA.

Widén, B. 2002. Seasonal variation in forest-floor $\mathrm{CO}_{2}$ exchange in a Swedish coniferous forest. Agricultural and Forest Meteorology 111:283-297.

Wisniewski, J. 1976. The occurrence rate of ants from the
Formica rufa-group in various phytosociologic associations. Oecologia 25:193-198.

Zahn, M. 1957. Temperatursinn, Wärmehaushalt und Bauweise der roten Waldameisen (Formica rufa L.). Zoologische Beiträge 3/2:127-194.

Zimmermann, P. R., J. P. Greenberg, S. O. Wandiga, and P. J. Crutzen. 1982. Termites: a potentially large source of atmospheric methane, carbon dioxide, and molecular hydrogen. Science 218:563-565. 